Email : uneslawreview@gmail.com Online : http://review-unes.com/index.php/law/index Volume 1, Issue 4, Juni 2019

E-ISSN : 2622-7045

P-ISSN : 2654-3605

\title{
PERLINDUNGANSAKSI PELAPOR DALAM PERKARA PENYALAHGUNAAN NARKOTIKA PADA TINGKAT PENYIDIKAN (Studi Pada Satuan Reserse Narkoba Kepolisian Resor Kota Padang)
}

\author{
Anton Amris \\ Program Magister Ilmu Hukum, Universitas Ekasakti \\ Email: antonamris89@gmail.com
}

\begin{abstract}
The protection of the reporter as a witness who is willing to provide information for the purpose of disclosing criminal acts of drug abuse is regulated in Article 5 of Law Number 31 Year 2014 concerning Protection of Witnesses and Victims and Article 100 of Law Number 35 Year 2009 concerning Narcotics. The need for reporters to be given protection is very important to increase the participation of the community in helping law enforcement officers prevent and eradicate and disclose the proliferation of narcotics circulation. But in practice there are still many witnesses who do not want to provide information due to the lack of adequate guarantees for the protection provided by law enforcement officials.
\end{abstract}

Kata Kunci: Perlindungan,Saksi, Tindak Pidana Narkotika

\section{PENDAHULUAN}

Peranan saksi dalam setiap perkara pidana sangat penting karena keterangan saksi sangat dibutuhkan dalam setiap tingkat pemeriksaan, yaitu pada tingkat penyidikan, penuntutan dan pemeriksaan di sidang pengadilan.Seorang saksi dianggap memiliki kemampuan yang dapat menentukan kemana arah putusan hakim, oleh karena itu, saksi sudah sepatutnya diberikan perlindungan hukum karena dalam mengungkap suatu tindak pidana saksi secara sadar mengambil resiko dalam mengungkap kebenaran materiil. $^{1}$

1 Muhadar, Perlindungan Saksi dan Korban Dalam Sistem Peradilan Pidana, Putra Media
Kedudukan saksi dalam proses peradilan pidana menempati posisi kunci, sebagaimana yang diatur dalam Pasal 184 Kitab Undang-undang Hukum Acara Pidana (KUHAP). Sebagai alat bukti utama, tentu dampaknya sangat terasa bila dalam suatu perkara tidak ada saksi. Pentingnya kedudukan saksi dalam proses peradilan pidana, telah dimulai sejak awal proses peradilan pidana.

Harus diakui bahwa terungkapnya kasus pelanggaran hukum sebagian besar berdasarkan informasi dari masyarakat. Begitu pula dalam proses selanjutnya, pada

Nusantara, Surabaya, 2010, hlm. 1. 
tingkat penyidikan di kepolisian, tingkat penunttan di kejaksaan sampai pada akhirnya di pengadilan, keterangan saksi sebagai alat bukti utama menjadi acuan hakim dalam memutus bersalah atau tidaknya terdakwa. Jadi jelas bahwa saksi mempunyai kontribusi yang sangat besar dalam upaya menegakkan hukum dan keadilan. ${ }^{2}$

Masalah narkotika merupakan masalah nasional dan internasional, karena penyalahgunaannya akan berdampak negatif terhadap kehidupan bermasyarakat, berbangsa, dan bernegara. Hal yang sama dirasakan di Indonesia dimana hampir setiap hari peredaran narkotika dan penyalahgunaannya, mulai dari tertangkapnya pengedar ataupun ditemukannya pabrik-pabrik narkotika hingga berita generasi muda yang tewas karena mengkonsumsi narkotika, tiada hentihentinya diberitakan di media cetak maupun media elektronik.

Angka penyalahgunaan narkoba dari tahun ke tahun mengalami peningkatan bahkan prediksi pada 2017 diperkirakan jumlah pengguna narkoba di Indonesia akan mencapai 5,8 juta jiwa. Hal ini karena jumlah pengguna narkotika untuk saat ini telah mencapai 4 juta jiwa. Angka penyalahgunaan narkoba setiap tahunnya terus meningkat di

${ }^{2}$ Surastini Fitriasih, "Perlindungan Saksi Dan Korban Sebagai Sarana Menuju Proses Peradilan (Pidana) Yang Jujur Adil”, http/www. antikorupsi.org $/ \bmod =$ tema\&op , diakses pada tanggal 8 November 2017 mana pada 2017 jumlah korban penyalahgunaan narkoba akan mencapai angka 6 juta jiwa. Kemudian di Indonesia saat ini sangat minim tempat rehabilitasi yang hanya bisa menampung 18 ribu orang sedangkan korban yang ada saat ini sebanyak 6 juta orang. ${ }^{3}$

Berbagai tindakan terus dilakukan oleh pemerintah untuk mencegah dan memberantas tindak pidana narkotika yang timbul dalam masyarakat, yaitu dengan cara: ${ }^{4}$ 1. Pre-emptive adalah pencegahan secara dini atau lebih awal, belum ada tandatanda kriminogen (faktor pencetus tindak kriminal);

2. Tindakan preventif adalah tindakan sebelum terjadinya kejahatan atau perbuatan yang melanggar hukum;

3. Tindakan represif adalah tindakan ini dimulai dari suatu adanya pelanggaran sampai pada suatu proses pengusutan, penuntutan dan penjatuhan pidana serta pelaksanaan pidana yakni menjerat pelaku dengan Undang-undang Nomor 35 Tahun 2009 tentang Narkotika.

Berdasarkan fakta yang ada, aparat penegak hukum hanya mampu menjebloskan pelaku yang sifatnya hanya "pemain kecil", yakni pengedar yang sifatnya hanya

${ }^{3}$ https://news.okezone.com/read/2017/07/20/337 /1740743/mencengangkan-pecandu-narkoba-diindonesia-tembus-6-juta-orang, diakses tanggal 10 November 2017

${ }^{4}$ Wresniworo, Masalah Narkotika dan Obatobatan Berbahaya, Mitra Bintimar, Jakarta, 2002, hlm. 33. 
menyalurkan narkotika tersebut, itupun dengan barang bukti yang hanya sedikit, tetapi tidak mampu untuk menjerat tokoh di balik jaringan besar ini. Hal ini di dasarkan dengan semakin meningkatnya kejahatan ini. ${ }^{5}$

Membantu aparat penegak hukum dalam hal mengungkap adanya tindak pidana narkotika yang terjadi merupakan suatu kewajiban setiap warga negara, namun di lain pihak apabila melaporkan peristiwanya tidak tertutup kemungkinan orang-orang yang terlibat peristiwa itu merasa tidak senang atau marah kepada orang yang bersaksi. Pada umumnya orang yang terlibat dalam peredaran gelap narkotika tidak bertindak sendirian, mereka berkawan, berkelompok atau diperkirakan tindak pidana ini juga terorganisasi, dimana ada yang bertindak sebagai pemasok bahan bakunya, ada yang bertindak sebagai produsen, bandar dan pengedar. Kalau sampai dilaporkan dan merasa akan terbongkar seluruh kegiatannya, besar kemungkinan mereka yang terlibat bukan hanya tidak senang dan marah saja, akan tetapi lebih dari itu, mereka akan main hakim sendiri dengan mengambil tindakan yang berakibat nasib buruk bagi saksi yang diketahuinya. ${ }^{6}$

Berdasarkan tindakan-tindakan yang akan mengancam keselamatan saksi tersebut,

5 Daan Sabadah dan Kunarto, Kejahatan Berdimensi Baru, Cipta Manunggal, Jakarta, 1999, hlm. 302

${ }^{6}$ Gatot Supranomo, Hukum Narkoba Indonesia, Djambatan, Jakarta, 2009, hlm. 102 maka perlu adanya suatu jaminan keamanan dan perlindungan dari pihak yang berwenang. Untuk itu tanpa diminta saksi, pihak yang berwenang harus memberikan jaminan keamanan dan perlindungan sebaik-baiknya terhadap saksi jika nantinya mengalami ancaman maupun intimidasi dari sindikat narkotika.Seperti dikatakan Leden Marpaung bahwa, "keterangan saksi diberikan tanpa adanya tekanan dari siapapun dan dalam bentuk apapun".?

Pentingnya jaminan keamanan dan perlindungan itu agar orang tidak merasa takut untuk melaporkan kejahatan yang berkaitan dengan tindak pidana narkotika, dan dengan jaminan yang nyata dan dapat dirasakan oleh seorang saksi, maka akan semakin banyak orang yang berani untuk menjadi saksi. Undang-undang Nomor 31 Tahun 2014 tentang Perubahan Atas Undangundang Nomor 13 Tahun 2006 tentang Perlindungan Saksi dan Korban diharapkan dapat memberikan perlindungan bagi saksi dan pelapor yang berintikan pada keadilan dan kebenaran serta mampu menjamin kepastian, ketertiban, penegakan dan perlindungan hukum bagi saksi serta menghargai hak asasi manusia yang menjadi hak bagi seorang saksi sehingga membantu dalam membuka tabir kejahatan perkara

${ }^{7}$ Leden Marpaung, Proses Penangaan Perkara Pidana Bagian Pertama Penyidikan dan Penyelidikan, Sinar Grafika, Jakarta, 1992, hlm 81. 
pidana dan mengungkap suatu kebenaran dari tindak pidana yang telah terjadi.

Berdasarkan latar belakang pemikiran di atas, maka permasalahan yang dibahas dalam tulisan ilmiah ini adalah sebagai berikut:

1. Bagaimanakah pelaksanaan perlindungan saksi pelapor dalam tindak pidana penyalahgunaan narkotika pada tingkat penyidikan di Satuan Reserse Narkoba Kepolisian Resor Kota Padang?

2. Apakah hambatan-hambatan yang dihadapi penyidik dalam memberikan perlindungan terhadap saksi pelapor dalam tindak pidana penyalahgunaan narkotika di Satuan Reserse Narkoba Kepolisian Resor Kota Padang?

\section{METODE PENELITIAN}

Penelitian ini adalah suatu penelitian yang bersifat deskriptif analitis, yaitu penelitian yang menggambarkan tentang pelaksanaan dan hambatan-hambatan yang dihadapi dalam perlindungan saksi pelapor dalam tindak pidana penyalahgunaan narkotika pada tingkat penyidikan di Satuan Reserse Narkoba Kepolisian Resor Kota Padang.Metode pendekatan yang digunakan dalam penelitian ini adalah yuridis normative, yang didukung pendekatan yuridis empiris. Pendekatan yuridis normative yaitu pendekatan yang dilakukan dengan cara mempelajari ketentuanketentuan dan peraturan perundang- undangan. Pendekatan yuridisempiris dilakukan dengan cara mengumpulkan semua bahan dan data yang diperoleh dari lapangan yang berhubungan dengan permasalahan yang diteliti.

\section{HASIL PENELITIAN DAN ANALISIS}

Pelaksanaan Perlindungan Saksi Pelapor Dalam Tindak Pidana Penyalahgunaan Narkotika Pada Tingkat Penyidikan di Satuan Reserse Narkoba Kepolisian Resor Kota Padang

Kepolisian memiliki peranan penting dalam mewujudkan keamanan dan kenyamanan dalam kehidupan bermasyarakat, kepolisian merupakan lembaga pengayom masyarakat dalam segala kondisi sosial yang caruk maruk.

Peran kepolisian dapat dikatakan sebagai aspek kedudukan yang berhubungan dengan kedudukanya sebagai pelindung masyarakat. ${ }^{8}$

Peredaran dan penyalahgunaan narkoba sudah sangat meresahkan, korban yang berjatuhanpun semakin banyak.Hal ini sebenarnya mengundang keprihatinan banyak pihak, hanya saja tak semua berani melakukan tindakan nyata.Sebagian warga masyarakat masih takut untuk melapor ke kepolisian maupun Badan Narkotika Nasional (BNN) meskipun mengetahui ada orang di sekitar lingkungannya terlibat dalam peredaran gelap narkotika.Sikap seperti ini

${ }^{8}$ Satjipto Rahardjo, Mengkaji Kembali Peran dan Fungsi Polri dalam Masyarakat di Era REformasi, FHUI, Jakarta, 1989, hlm. 7. 
tentunya sangat bertentangan dengan semangat pemberantasan penyalahgunaan narkotika di Indonesia.Padahal dalam Undang-undang Nomor 35 Tahun 2009 tentang Narkotika secara tegas memposisikan pelapor sebagai pihak yang harus dilindungi.Undang-undang narkotika memberikan jaminan keamanan bagi orangorang yang memberikan informasi valid tentang adanya penyalahgunaan dan peredaran gelap narkotika.

Menurut Pasal 104 Undang-undang Nomor 35 Tahun 2009 tentang Narkotika disebutkan bahwa:"masyarakat mempunyai kesempatan yang seluas-luasnya untuk berperan serta membantu pencegahan dan pemberantasan penyalahgunaan dan peredaran gelap narkotika dan prekursor narkotika. Lebih lanjut dijabarkan dalam Pasal 105 Undang-undang Nomor 35 Tahun 2009 tentang Narkotika yang menyebutkan bahwa:"masyarakat juga mempunyai hak dan tanggung jawab dalam upaya pencegahan dan pemberantasan penyalahgunaan dan peredaran gelap narkotika dan prekursor narkotika.

Mengenai kehawatiran masyarakat terhadap ancaman bahkan yang bisa membahayakan nyawa bila melaporkan adanya peredaran dan penyalahgunaan narkoba, sesungguhnya sudah dijawab dengan tegas sebagaimana yang diatur dalam Pasal 100 ayat (1) Undang-undang Nomor 35
Tahun 2009 tentang Narkotika yang menyebutkan bahwa:

"saksi, pelapor, penyidik, penuntut umum dan hakim yang memeriksa perkara tindak pidana narkotika dan prekursor narkotika dan keluarganya wajib diberi perlindungan oleh negara dari ancaman yang membahayakan diri, jiwa dan hartanya, baik sebelum selama maupun sesudah proses pemeriksaan perkara".

Perlindungan terhadap pelapor bahkan tetap dijamin hingga ke persidangan sebagaimana diamanatkan Pasal 106 huruf e Undang-undang Nomor 35 Tahun 2009 tentang Narkotika yang menegaskan bahwa:"pelapor juga memperoleh perlindungan hukum pada saat yang bersangkutan melaksanakan haknya atau diminta hadir dalam proses peradilan. Tidak hanya berhenti sampai di situ saja. Pelapor juga akan mendapatkanpenghargaan (reward) dari pemerintah.

Mengenai penghargaan tersebut, hal itu ditegaskan dalam Pasal 109Undangundang Nomor 35 Tahun 2009 tentang Narkotika bahwa:"pemerintah memberikan penghargaan kepada penegak hukum dan masyarakat yang telah berjasa dalam upaya pencegahan, pemberantasan penyalahgunaan dan peredaraan gelap narkotika dan prekursor narkotika. Dalam penjelasan Pasal 109 disebutkan dalam pemberian penghargaan juga harus tetap memperhatikan jaminan keamanan dan perlindungan terhadap yang diberi penghargaan.Penghargaan yang 
diberikan itu bisa dalam bentuk piagam, tanda jasa, premi dan bentuk lainnya.

Berdasarkan hasil penelitian yang penulis lakukan diperoleh penjelasan bahwa pelaksanaan perlindungan saksi pelapor dalam tindak pidana penyalahgunaan narkotika pada tingkat penyidikan di Satuan Reserse Narkoba Kepolisian Resor Kota Padang dilakukan dengan bentuk-bentuk sebagai berikut: ${ }^{9}$

\section{Perlindungan Secara Yuridis}

Dalam memberikan perlindungan secara yuridis, pihak Satuan Reserse Narkoba Kepolisian Resor Kota Padang memberikan penjelasan kepada pelapor mengenai hak-haknya sebagai saksi akan diberikan dan dijamin kerahasiaannya dan diperlakukan secara baik dalam proses pemeriksaan serta mendapat jaminan dari penyidik bahwa apapun keterangan yang diberikan saksi kepada penyidik tidak akan berdampak secara hukum kepasa pelapor, karena penyidik akan memberikan jaminan hukum secara penuh bahwa pelapor tidak dapat digugat, baik secara perdata maupun pidana terhadap keterangan yang diberikan tersebut.Selanjutnya dijelaskan bahwa yang dilakukan pihak kepolisian dalam melaksanakan perlindungan terhadap saksi pelapor terlihat jelas bahwa saksi telah dilindungi secara hukum. Saksi pelapor

9 Hasil wawancara dengan Bapak Komisaris Polisi (Kompol) Abriadi, S.H., Kepala Satuan Reserse Narkoba (Kasatresnarkoba) Kepolisian Resor Kota Padang pada tanggal 17 Oktober 2018 di Padang. juga diperlakukan dengan baik dalam proses penyidikan. Hal ini sudah seharusnya terjadi karena sudah adanya jaminan dari Undang-undang Nomor 31 Tahun 2014 tentang Perubahan Atas Undang-undang Nomor 13 Tahun 2006 tentang Perlindungan Saksi dan Korban. ${ }^{10}$

2.Perlindungan Atas Keamanan Pribadi Saksi, baik Fisik Maupun Mental

$$
\text { Satuan Reserse Narkoba }
$$

(Satresnarkoba) Kepolisian Resor Kota Padang dalam memberikan perlindungan akan keamanan pribadi saksi, dan apabila dirasa perlu, seorang saksi harus ditempatkan dalam suatu tempat yang dirahasiakan dari siapapun untuk menjamin agar ia aman. Ketika saksi tidak diberikan perlindungan semacam ini maka aka nada kekhawatiran dari saksi dan ketakutan untuk memberikan keterangan karena adanya kekhawatiran dari saksi bahwa tersangka atau terdakwa akan membalas dendam maupun membahayakan jiwa keamanan saksi, pelapor maupun korban. ${ }^{11}$ Seorang saksi jika tidak diberikan perlindungan maka saksi akan merasa takut untuk memberikan keterangan dalam setiap proses peradilan pidana. Adapun tujuan

${ }^{10}$ Hasil wawancara dengan Inspektur Polisi Dua (Ipda) Nofridal, S.H., Kepala Unit Penyidikan (Kanit Idik) II Satuan Reserse Narkoba (Satresnarkoba) Kepolisian Resor Kota Padang pada tanggal 25 Oktober 2018 di Padang.

11 Hasil wawancara dengan Bapak Komisaris Polisi (Kompol) Abriadi, S.H., Kepala Satuan Reserse Narkoba (Kasatresnarkoba) Kepolisian Resor Kota Padang pada tanggal 17 Oktober 2018 di Padang. 
diberikannya hak saksi dan pelapor ini adalah untuk memacu saksi dalam memberikan keterangan tentang suatu tindak pidana.Sehingga aparat dalam mengungkap suatu tindak pidana sangat tertolong dengan adanya keberanian saksi untuk memberikan keterangan dan informasi yang diketahuinya. ${ }^{12}$

3.Penyamaran Identitas Saksi

Pelaksanaan perlindungan bagi saksi pelapor oleh Satuan Reserse Narkoba (Satresnarkoba) Kepolisian Resor Kota Padang, yaitu dengan memberikan penyamaran identitas bagi saksi masyarakat dengan cara merahasiakan nama, tempat tinggal dan identitas lainnya pada tingkat penyidikan.Begitu juga pada tingkat persidangan, saksi penangkap (Polisi) tidak menyebutkan identitasnya di depan persidangan. Saksi penangkap tersebut tidak memberitahukan identitas dari saksi masyarakat yang telah memberikan keterangannya.Saksi penangkap memberikan keterangan berdasarkan apa yang diketahui dan berdasarkan keterangan yang diberikan oleh saksi tersebut di persidangan. ${ }^{13}$ Selanjutnya dijelaskan bahwa pada persidangan tindak pidana

${ }^{12}$ Hasil wawancara dengan Bapak Komisaris Polisi (Kompol) Abriadi, S.H., Kepala Satuan Reserse Narkoba (Kasatresnarkoba) Kepolisian Resor Kota Padang pada tanggal 17 Oktober 2018 di Padang.

${ }_{13}$ Hasil wawancara dengan Bapak Komisaris Polisi (Kompol) Abriadi, S.H., Kepala Satuan Reserse Narkoba (Kasatresnarkoba) Kepolisian Resor Kota Padang pada tanggal 17 Oktober 2018 di Padang. narkotika, jarang sekali saksi itu dihadirkan dan biasanya yang dihadirkan adalah saksi penangkap (Polisi) dan saksi mahkota, sehingga keterangan yang disampaikan adalah keterangan yang berasal dari saksi masyarakat bahwa masyarakatlah yang memberitahukan bahwa ada yang sedang melakukan transaksi atau menggunakan narkotika. ${ }^{14}$

Hambatan-Hambatan Yang Dihadapi Penyidik Dalam Memberikan Perlindungan Terhadap Saksi Pelapor Dalam Tindak Pidana Penyalahgunaan Narkotika di Satuan Reserse Narkoba Kepolisian Resor Kota Padang.

Berdasarkan hasil penelitian yang penulis lakukan diperoleh penjelasan bahwa hambatan-hambatan yang dihadapi penyidik dalam memberikan perlindungan terhadap saksi pelapor dalam tindak pidana penyalahgunaan narkotika di Satuan Reserse Narkoba Kepolisian Resor Kota Padang, yaitu:

1. Saksi pelapor tidak berani hadir pada proses penyidikan.

Hambatan yang dihadapi Satresnarkoba Polresta Padang dalam perlindungan hukum bagi saksi pelapor tindak pidana penyalahgunaan narkotika adalah saksi pelapor merasa di bawah ancaman, saksi merasa takut apabila memberikan laporan atau kesaksian dari

${ }^{14}$ Hasil wawancara dengan Inspektur Polisi Dua (Ipda) Nofridal, S.H., Kepala Unit Penyidikan (Kanit Idik) II Satuan Reserse Narkoba (Satresnarkoba) Kepolisian Resor Kota Padang pada tanggal 25 Oktober 2018 di Padang. 
suatu tindak pidana narkotika dan tidak maunya saksi memberikan kesaksian karena banyaknya tekanan-tekanan dari pelaku atau pihak-pihak lain, sehingga penyidik tidak dapat menghadirkan saksi pada proses penyidikan. ${ }^{15}$

2. Kurangnya Partisipasi Masyarakat dalam melaporkan tindak pidana narkotika.

Tindak pidana narkotika sebagai tindak pidana khusus dan jaringannya sangat luas dan berbahaya, sehingga tidak heran jika banyak masyarakat yang tidak berani melaporkannya kepada pihak yang berwajib, dikarenakan masyarakat takut jika tindakannya itu dapat membahayakan diri dan keluarganya.Kondisi yang demikian inilah yang dialami Satuan Reserse Narkoba Kepolisian Resor Kota Padang, dalam memberantas tindak pidana narkotika.Kurangnya keberanian dan partisipasi masyarakat inilah yang menjadi hambatan. ${ }^{16}$

3. Banyaknya masyarakat yang tidak tahu undang-undang perlindung-an saksi dan korban

Walaupun Kota Padang sebagai Ibu Kota Provinsi Sumatera Barat, namun masih banyak ditemui masyarakat yang

${ }^{15}$ Hasil wawancara dengan Inspektur Polisi Dua (Ipda) Nofridal, S.H., Kepala Unit Penyidikan (Kanit Idik) II Satuan Reserse Narkoba (Satresnarkoba) Kepolisian Resor Kota Padang pada tanggal 25 Oktober 2018 di Padang.

${ }^{16}$ Hasil wawancara dengan Inspektur Polisi Dua (Ipda) Nofridal, S.H., Kepala Unit Penyidikan (Kanit Idik) II Satuan Reserse Narkoba (Satresnarkoba) Kepolisian Resor Kota Padang pada tanggal 25 Oktober 2018 di Padang. tidak tahu adanya Undang-undang Nomor 31 Tahun 2014 tentang Perubahan Atas Undang-undang Nomor 13 Tahun 2006 tentang Perlindungan Saksi dan Korban. Tidak sedikit masyarakat yang tahu adanya undang-undang perlindungan saksi dan korban ini, sehingga masyarakat khawatir untuk melaporkannya atau menjadi saksi di persidangan. Banyak masyarakat yang menolak menjadi saksi dikarenakan mereka takut kesaksiannya akan mengancam keselamatan dirinya dan keluarganya. Masyarakat tidak tahu bahwa mereka bisa mendapatkan perlindungan dalam bentuk perlindungan atas keamanan pribadi, baik fisik maupun mental dan perlindungan secara yuridis dan penyamaran identitas saksi. ${ }^{17}$

4. Banyaknya saksi yang meragukan perlindungan yang akan diberikan oleh aparat Kepolisian

Masyarakat pada umumnya khawatir dan takut untuk memberikan kesaksiannya karena dapat membahayakan diri dan keluarganya, walaupun sesugguhnya sudah ada undang-undang perlindungan saksi dan korban, tetapi tetap saja mereka punya perasaan khawatir untuk melaporkan tindak pidana penyalahgunaan narkoba. Hal ini

${ }^{17}$ Hasil wawancara dengan Inspektur Polisi Dua (Ipda) Nofridal, S.H., Kepala Unit Penyidikan (Kanit Idik) II Satuan Reserse Narkoba (Satresnarkoba) Kepolisian Resor Kota Padang pada tanggal 25 Oktober 2018 di Padang. 
disebabkan karena masyarakat masih meragukan perlindungan yang akan diberikan oleh aparat kepolisian. Mereka takut jika petugas kepolisian tidak melindunginya dengan baik dan takut ancaman akan datang ketika petugas tidak melindunginya lagi. ${ }^{18}$

5. Kurangnya kesadaran aparat penegak hukum

Perlindungan saksi dalam tindak pidana narkotika dalam implementasinya mengalami hambatan akibat kurangnya kesadaran aparat penegak hukum tentang pentingnya perlindungan saksi.Harus diakui bahwa aparat penegak hukum jarang berupaya untuk memberikan informasi tentang perlindungan saksi dan kurang memberikan informasi tentang bentuk-bentuk perlindungan saksi yang diberikan oleh aparat kepolisian.Selain itu kinerja penyidik di lapangan kurang dalam mencari saksi masyarakat. Itulah sebabnya tidak adanya masyarakat saksi yang bisa dihadirkan dalam proses penyidikan. ${ }^{19}$

6. Kurangnya anggaran operasional bagi program perlindungan saksi

Di samping hambatan dalam mencari

${ }^{18}$ Hasil wawancara dengan Inspektur Polisi Dua (Ipda) Nofridal, S.H., Kepala Unit Penyidikan (Kanit Idik) II Satuan Reserse Narkoba (Satresnarkoba) Kepolisian Resor Kota Padang pada tanggal 25 Oktober 2018 di Padang.

${ }_{19}$ Hasil wawancara dengan Bapak Komisaris Polisi (Kompol) Abriadi, S.H., Kepala Satuan Reserse Narkoba (Kasatresnarkoba) Kepolisian Resor Kota Padang pada tanggal 17 Oktober 2018 di Padang saksi masyarakat, hambatan lain yang menyulitkan perlindungan saksi ini adalah masalah dana bagi program perlindungan saksi. Apabila ada saksi masyarakat yang mau meminta perlindungan kepada anggota kepolisian, mungkin akan menyulitkan anggota kepolisian tersebut dalam memberikan perlindungan, ini terkait dengan kurangnya anggaran operasional bagi program perlindungan saksi. $^{20}$

7. Terbatasnya sarana dan fasilitas dalam melakukan perlindungan saksi

Tindak pidana narkotika tidak lagi dilakukan secara perseorangan, melainkan melibatkan banyak orang yang secara bersama-sama, bahkan merupakan sindikat yang terorganisasi dengan jaringan yang luas yang bekerja secara rapi dan sangat rahasia baik ditingkat nasional dan internasional.Ada beberapa kendala dalam melakukan perlindungan saksi dan pelapor dalam tindak pidana narkotika. Salah satunya adalah dana operasional dan fasilitas dalam melaksanakan perlindungan saksi dan pelapor. Proses perlindungan saksi dan pelapor tentu membutuhkan dana dan fasilitas yang cukup, sayangnya hal tersebut sangat terbatas. Sarana dan

${ }^{20}$ Hasil wawancara dengan Inspektur Polisi Dua (Ipda) Nofridal, S.H., Kepala Unit Penyidikan (Kanit Idik) II Satuan Reserse Narkoba (Satresnarkoba) Kepolisian Resor Kota Padang pada tanggal 25 Oktober 2018 di Padang. 
Fasilitas dalam melakukan perlindungan saksi dan pelapor kurang mendapat perhatian dari Pemerintah sehingga dalam merealisasikan perlindungan yang ada di dalam undang-undang menjadi sulit. ${ }^{21}$

\section{PENUTUP}

Pelaksanaan perlindungan saksi pelapor dalam tindak pidana penyalahgunaan narkotika pada tingkat penyidikan di Satuan Reserse Narkoba Kepolisian Resor Kota Padangdilakukan berdasarkan undang-undang perlindung-an saksi dan korban serta undang-undang narkotika dan peraturan pemerintah tentang pelaksanaan perlindungan saksi dan korban dengan 3 (tiga) bentuk perlindungan, yaitu: pertama, perlindungan hukum, kedua, perlindungan atas keamanan pribadi saksi, baik fisik maupun mental dan ketiga, penyamaran identitas saksi.

Hambatan-hambatan yang dihadapi penyidik dalam memberikan perlindungan terhadap saksi pelapor dalam tindak pidana penyalahgunaan narkotika di Satuan Reserse Narkoba Kepolisian Resor Kota Padang yaitu: (1) saksi pelapor tidak berani hadir pada

${ }^{21}$ Hasil wawancara dengan Inspektur Polisi Dua (Ipda) Nofridal, S.H., Kepala Unit Penyidikan (Kanit Idik) II Satuan Reserse Narkoba (Satresnarkoba) Kepolisian Resor Kota Padang pada tanggal 25 Oktober 2018 di Padang. proses penyidikan, (2) kurangnya partisipasi masyarakat dalam melaporkan tindak pidana narkoba, (3) banyak masyarakat yang tidak tahu adanya undang-undang perlindungan saksi dan korban, (4) banyaknya saksi yang meragukan perlindungan dari kepolisian, (5) kurangnya kesadaran aparta penegak hukum, (6) kurangnya anggaran operasional untuk program perlindungan saksi serta (7) terbatasnya sarana dan fasilitas dalam melakukan perlindungan saksi.

\section{DAFTAR PUSTAKA}

\section{Buku-Buku}

Adhi Wibowo, Hukum Acara Pidana Dalam Teori dan Praktik, Hayfa Press, Padang, 2012

Andi Hamzah, Hukum Acara Pidana Indonesia,Sinar Grafika, Jakarta, 2001

Daan Sabadah dan Kunarto, Kejahatan Berdimensi Baru, Cipta Manunggal, Jakarta, 1999

Dudu Duswara Machmudin, Pengantar Ilmu Hukum Sebuah Sketsa, Refika Aditama, Bandung, 2013

Gatot Supranomo, Hukum Narkoba Indonesia, Djambatan, Jakarta, 2009

Lilik Mulyadi, Bunga Rampai Hukum Pidana Perspektif, Teoritis Dan Praktik, PT. Alumni, Bandung, 2008 
Moch Faisal Salam, Hukum Acara Pidana Dalam Teori dan Praktek, Mandar Maju, Bandung, 2001

Muhadar, Perlindungan Saksi dan Korban Dalam Sistem Peradilan Pidana, Putra Media Nusantara, Surabaya, 2010

O.C Kaligis, Narkotika dan Peradilannya Di Indonesia, Alumni, Bandung, 2002

Philipus M. Hadjon, Perlindungan Hukum Bagi Rakyat Di Indonesia: Sebuah Studi Tentang Prinsip-Prinsipnya, Penanganannya Oleh Pengadilan Dalam Lingkungan Peradilan Umum Dan Pembentukan Peradilan Adminstrasi Negara, Bina Ilmu, Jakarta, 1987

Rido Triawan dan Supriyadi Widodo Eddyono, Membongkar Kebijakan Narkotika, Mandar Maju, Bandung, 2015

Ronny Hanitijo Soemitro, Metodologi Penelitian Hukum dan Jurimetri, Ghalia Indonesia, Jakarta, 1990

Satjipto Rahardjo, Mengkaji Kembali Peran dan Fungsi Polri dalam Masyarakat di Era REformasi, Makalah Seminar Polisi dan Masyarakat Dalam Era Reformasi, FHUI, Jakarta, 1989

Satuan Tugas Pemberantasan Mafia Hukum, Perlindungan terhadap saksi pelaku yang bekerjasama (Justice Collaborators), Satgas PMH, Cetakan Kedua, 2011

Wresniworo, Masalah Narkotika dan Obatobatan Berbahaya, Mitra Bintimar, Jakarta, 2002

Zahirin Harahap, Hukum Acara Peradilan Tata Usaha Negara, Raja Grafindo, Jakarta, 2001

\section{Peraturan Undang-Undang}

Kitab Undang-Undang Acara Pidana

Undang-undang Nomor 35 Tahun 2009 tentang Narkotika
Undang-undang Nomor 31 Tahun 2014 tentang Perubahan Atas Undangundang Nomor 13 Tahun 2006 tentang Perlindungan Saksi dan Korban 